\section{Ornithine transcarbamylase polymorphism detected by PCR introduction of Dral site}

E.M.Petty, R.Carstens and A.E.Bale

Department of Human Genetics, Yale University School of Medicine, 333 Cedar Street, New Haven, CT 06510, USA

Description: Primers O 46 (5' GTGACCTTCTCACTTTAA) and T 46 (5' AGAGAAAATGTTACATACC) were designed to amplify a 116 bp segment of ornithine transcarbamylase (OTC) exon 2. Both AAA and AGA sequences have been reported in normal individuals at nucleotide positions 138-140 corresponding to amino acid position $46(1,2)$. Although this variation does not alter a restriction site, introduction into the PCR product of a $T$ instead of the native sequence $G$ at nucleotide position 135 by use of primer $\mathrm{O} 46$ creates a DraI site when the AAA but not AGA codon is present.

Protocol: $100 \mu \mathrm{l}$ volume reactions of $.5 \mu \mathrm{g}-10 \mu \mathrm{g}$ genomic DNA, .3 U Promega TAQ DNA polymerase, $200 \mu \mathrm{M}$ of each $\mathrm{dNTP}, 1 \mu \mathrm{M}$ of each primer, $.5 \mu \mathrm{M}$ of spermidine, and $1 \times$ Promega PCR buffer underwent 35 cycles of PCR $\left(95^{\circ} \mathrm{C} \times 1\right.$ min., $50^{\circ} \mathrm{C} \times 1 \mathrm{~min} ., 72^{\circ} \mathrm{C} \times 2 \mathrm{~min}$.) followed by $72^{\circ} \mathrm{C} \times 5 \mathrm{~min}$. final extension. $25 \mu \mathrm{l}$ of PCR product was digested with $20 \mathrm{U}$ DraI $\left(37^{\circ} \mathrm{C} \times 2\right.$ hours $)$ and analyzed by agarose gel electrophoresis (3\% NuSieve GTG and 1\% Seakem LE).

Polymorphism: DraI digestion of PCR products distinguished a two allele polymorphism with $100 \mathrm{bp}$ and $16 \mathrm{bp}$ fragments when the AAA codon was present and a $116 \mathrm{bp}$ fragment when AGA was present.

Frequency: Estimation is based on the study of 56 chromosomes from unrelated individuals.

AAA codon (110 bp): 0.68

AGA codon (116 bp): 0.32

Gene Localization: The OTC gene was mapped to Xp21.1 by Lindgren et al. (3). The PCR polymorphism co-segregates with the BamHI OTC RFLPs in one kindred and DMD RFLPs in a second kindred.

Mendelian Inheritance: X-linked segregation was demonstrated in individuals from 82 - and 3-generation families.

Other Comments: There is no evidence for linkage disequilibrium with the OTC MspI RFLPs detected with pH0731.

References: 1) Hata,A. et al. (1988) J. Biochem. 103, 302-308. 2) Horwich,A.L. et al. (1984) Science 224, 1068-1074. 3) Lindgren,V: et al. (1984) Science 226, 698-700.

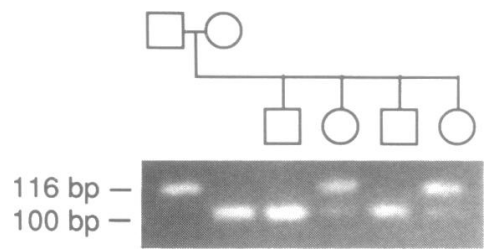

\section{Bgl-I and Kpn-I RFLPs at the human liver/islet glucose transporter (GLUT2) gene locus}

S.-R.Li, R.Oelbaum, J.Stocks ${ }^{\star}$, P.Bouloux, M.Baroni, J.Alcolado and D.Galton

Department of Human Genetics and Metabolism, St: Bartholomew's Hospital, London EC1A 7BE, UK

Source/Description: pSPGT 2 contains a cDNA corresponding to the human liver/islet glucose transporter entire cDNA and 10 bp of the $5^{\prime}$ and $900 \mathrm{bp}$ of the $3^{\prime}$ region (1).

Polymorphisms: Bgl-I detects invariant bands at 12.6 and $7.9 \mathrm{~kb}$ and a two allele polymorphism with bands at 4.2 and $4.0 \mathrm{~kb}$. This RFLP can also be detected with Hind-III. Kpn-I detects invariant bands at 9.0 and $4.7 \mathrm{~kb}$ and a dimorphism with the presence or absence of a band at $2.8 \mathrm{~kb}$.

Frequency: Bgl-I: studied in 36 Caucasians, $\mathrm{Cl}: 4.2 \mathrm{~kb}$ band $=$ $0.1 ; \mathrm{C} 2: 4.0 \mathrm{~kb}$ band $=0.90$. Kpn-I studied in 30 Caucasians, presence of D1: $2.8 \mathrm{~kb}$ band $=0.25$; absence of D2: $2.8 \mathrm{~kb}$ band $=0.75$.

Not Polymorphic For: Ava-II, Bgl-II, Bst-I, Msp-I, Pst-I, PvuII, Rsa-I, Sst-I, Stu-I, Xba-I, Xmn-I.

Chromosomal Localization: 3q26.1-q 26.3 (1).

Mendelian Inheritance: Bgl-I: co-dominant segregation observed in 3 families with 13 members. Kpn-I: co-dominant segregation observed in 2 families with 9 individuals.

Probe Availability: Request for probe to G.I. Bell at Howard Hughes Medical Institute and Departments of Biochemistry and Molecular Biology, the University of Chicago, IL 60637, USA.

Acknowledgements: Prof. G.I. Bell and British Diabetic Association.

Reference: 1) Fukumoto,H., Seino,S., Imura,H., Seino,Y., Eddy,R.L., Fukoshima,Y., Byers,M.G. and Shows,T.B. (1988) Proc. Natl. Acad. Sci. USA 85, 5434-5438.

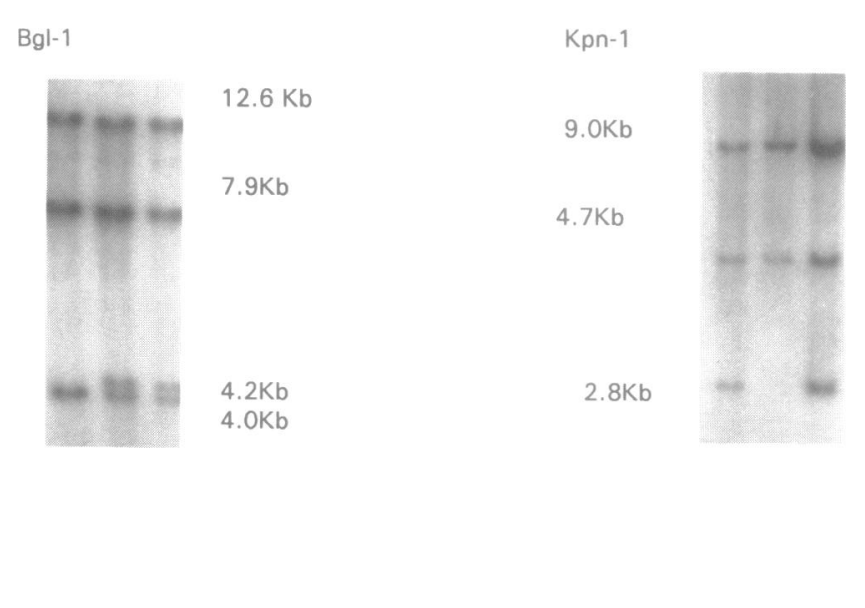

* To whom correspondence should be addressed 